\title{
Effectiveness of Nitrification Inhibition through Addition of Local Litter to Corn Plants in Andisols
}

\author{
Andita Sari P.W ${ }^{1}$, Lintang Panjali S.P ${ }^{1}$, Purwanto $^{2}$, Sri Hartati $^{2} \&$ Supriyadi $^{2}$ \\ ${ }^{1}$ Student of Department Soil Science, Sebelas Maret University, Surakarta, Indonesia \\ ${ }^{2}$ Department of Soil Science, Sebelas Maret University, Surakarta, Indonesia \\ Correspondence: Supriyadi, Department of Soil Science, Faculty of Agriculture, Sebelas Maret University, Jl. Ir. \\ Sutami 36A Surakarta 57126, Indonesia.
}

Received: April 13, 2020

doi:10.5539/mas.v14n7p120
Accepted: June 29, 2020

Online Published: June 30, 2020

\begin{abstract}
Nitrification is the oxidation process of $\mathrm{NH}_{4}^{+}$to $\mathrm{NO}_{3}{ }^{-}$microbially. The nitrification process can produce compounds in the form of $\mathrm{NO}_{3}^{-}, \mathrm{N}_{2} \mathrm{O}$, or $\mathrm{NO}$ which can cause environmental pollution through water, soil, or air, thus harming living things. The research was conducted to find ways to inhibit or control nitrification effectively and sustainably. The experiment was carried out in a plastic greenhouse located in Plesungan, Karanganyar until the maximum vegetative planting period of corn around May-June using a completely randomized design three replications. Andisols soil media was taken from Tegalrejo Village, Tengaran District, Semarang Regency

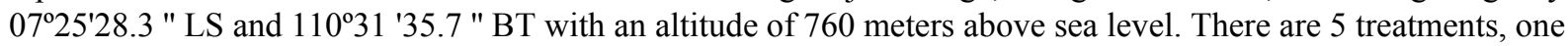
control, four are natural inhibitor treatments in the form of litter addition. The litter used was Gliricidia maculate, Albizzia falcataria, Senna siamea, and Tithonia diversifolia. Statistical analysis showed that treatment just significantly affect $\mathrm{NO}_{2}^{-}$concentrations (potential nitrification), not significantly affect $\mathrm{NH}_{4}^{+}, \mathrm{NO}_{3}{ }^{-}$ concentrations, and efficiency utilization of $\mathrm{N}$. However, measurement results in the laboratory and field showed that the addition of local litter could inhibit nitrification, which was demonstrated through the efficiency of $\mathrm{N}$ utilization. Tithonia diversifolia because it has the highest average $\mathrm{N}$ utilization efficiency of $25.79 \%, 58.71 \%$ more efficient than control treatments. Also followed by plant growth results showed that the root's dry weight and canopy's dry weight positively correlated with $\mathrm{NH}_{4}{ }^{+}$concentrations and efficient utilization of $\mathrm{N}$, also canopy's dry weight negatively correlated with $\mathrm{NO}_{2}{ }^{-}$concentrations (potential nitrification). The highest results occurred in the Tithonia diversifolia treatment.
\end{abstract}

Keywords: efficiency of $\mathrm{N}$ utilization, local litter, nitrification inhibition, potential nitrification

\section{Introduction}

Nitrogen fertilizer is the most widely used fertilizer $(300-350 \mathrm{~kg} / \mathrm{ha})$ in corn plants. However, it is also the least utilized in soil (only $40 \%$ - 50\%) compared to other nutrients. Excessive application of $\mathrm{N}$ fertilizer can cause problems, for example, the change from an immobilized form of nitrogen, $\mathrm{NH}_{4}{ }^{+}$in a more mobile form to $\mathrm{NO}_{2}{ }^{-}$ and $\mathrm{NO}_{3}{ }^{-}$biochemically by chemoautotrophs bacteria called the nitrification process (Philippot \& Germon, 2005).

$\mathrm{NH}_{4}^{+}$cations can be absorbed in 2: 1 type clay minerals, organic colloids, and/or are nitrified to $\mathrm{NO}_{3}{ }^{-}$. Meanwhile, $\mathrm{NO}_{3}^{-}$anions are mobile in soil solution. Therefore, the oxidation of $\mathrm{NH}_{4}{ }^{+}$into $\mathrm{NO}_{3}^{-}$, which is commonly called the nitrification process, in the soil needs to be controlled because it causes inefficiency of nitrogen fertilization. Through nitrification, most of the $\mathrm{N}$ in the soil will vanish in the form of $\mathrm{N}$-gas $\left(\mathrm{N}_{2} \mathrm{O}, \mathrm{NO}_{2}\right.$, $\mathrm{NO}$, and $\left.\mathrm{N}_{2}\right)$ and/or nitrate leachate $\left(\mathrm{NO}_{3}\right)$. The $\mathrm{NO}_{3}$ leaching will be followed by leaching of base cations in the soil $\left(\mathrm{K}^{+}, \mathrm{Ca}^{2+}\right.$, and $\left.\mathrm{Mg}^{2+}\right)$ thereby reducing base saturation, increasing soil acidity which eventually worsens the chemical nature of the soil (Raun and Johnson, 1999). Andisol is dominated by amorphous minerals, sufficient numbers of micropores, especially the intraparticle and interparticle pores of allophane. Andosol soil has various textures from sandy loam to sticky sandy (BBSLDP, 2014). The high number of soil pores creates an aerobic condition, triggering the high level of nitrification. Besides, Andisols which have high soil organic matter content can increase the population of nitrifier bacteria. Naturally, fertile soil has a higher nitrifying bacterial population and if added with $\mathrm{N}$ fertilizer, the bacterial population will increase. 
In general, nitrification needs to be inhibited because $\mathrm{NO}_{3}{ }^{-}$products leached into the watery area can cause eutrophication. Eutrophication can reduce dissolved oxygen concentration, increase concentrations of $\mathrm{N}_{2} \mathrm{O}$ and NO (greenhouse gases), and other detrimental environmental pollution (Cantarella et al., 2008; Dall'Orsoletta, Rauber, Schmitt, Gatiboni, \& Orsolin, 2017; Li et al., 2014). According to Butterbach-Bahl, Baggs, Dannenmann, Kiese, \& Zechmeister-Boltenstern (2013), the concentration of nitrous oxide $\left(\mathrm{N}_{2} \mathrm{O}\right)$ in the atmosphere is more persistent, causing 298 times higher global warming risk compared to that of carbon dioxide $\left(\mathrm{CO}_{2}\right)$, and that number may keep increasing. In soil, $\mathrm{N}_{2} \mathrm{O}$ is produced as an intermediary in several microbially driven processes consisting of nitrification and denitrification (Braker \& Conrad, 2011). According to Byrnes et al. (2017) and Van Groenigen et al. (2015), it is known that nitrification and denitrification represent critical pathways for nitrogen $(\mathrm{N})$ loss. The natural mechanism in inhibiting nitrification includes differences in affinity between plants, heterotrophic microbes, and nitrifying bacteria that compete to obtain $\mathrm{NH}_{4}{ }^{+}$; removal of root exudates that are toxic to nitrifying bacteria; the spatial separation between $\mathrm{NH}_{4}^{+}$sources and decomposers competing to obtain $\mathrm{NH}_{4}{ }^{+}$, especially between bacteria nitrification that requires with $\mathrm{NH}_{4}{ }^{+}$source (Verhagen, 1997). Nitrification is influenced by the availability of $\mathrm{NH}_{4}{ }^{+}$substrate, nitrifying bacterial population and environmental factors such as SOM (Soil Organic Matter) content, soil C / N ratio, the concentration of base cations, aeration, drainage, temperature, soil moisture and the presence of nitrifying inhibiting compounds (Myrold, Bottomley, Schepers, \& Raun, 2008).

According to Mancinelli \& McKay (1988), one effort to control the rate of nitrification is by litter input, thereby increasing the immobilization of $\mathrm{NH}_{4}^{+}$(nitrifying substrate) and $\mathrm{O}_{2}$ competition between heterotrophic bacteria and nitrifying bacteria. The litter quality factors that inhibit soil potential nitrification are polyphenol, lignin, ratio $(\mathrm{L}+\mathrm{P}) / \mathrm{N}$ and $\mathrm{C} / \mathrm{N}$ ratio. By balancing the $\mathrm{N}$ immobilization and nitrification processes in the soil, it is expected to optimize the utilization of $\mathrm{N}$ fertilizer inputs and to reduce $\mathrm{N}$ losses from the soil, thereby reducing the environmental impact.

\subsection{Introduce the Problem}

This study aims to answer the following question :

How to increase the efficiency of $\mathrm{N}$ utilization on corn plants in Andisols?

\subsection{Target and Inquires of Study}

The study goal is to prove the effect of litter addition on the efficiency of $\mathrm{N}$ utilization in corn in Andisols through the following questions :

Question 1: How does the addition of litter affect the efficiency of $\mathrm{N}$ utilization by corn (Zea mays) in Andisols?

Question 2: Which treatment is most effective in increasing the efficiency of $\mathrm{N}$ utilization by corn (Zea mays) in Andisols?

\subsection{Importance of the Study}

It is expected that the following entities will get benefit from the results of this study :

Provide new knowledge regarding the ability of litter as a natural inhibitor of nitrification in increasing the efficiency of $\mathrm{N}$ utilization as one of the environmentally friendly agricultural environmental management.

\subsection{Limitation}

The study is limited in the following:

Place: In the corn plants in Andisols

Time: Corn plants up to a maximum vegetative period

\subsection{Previous Related Research}

Some of the relevant studies are presented below for benefiting from their methodological procedures and theoretical literature they have included. They have been chronologically arranged from the oldest to latest :

A study by Krave, A. S., Van Straalen, N. M., \& Van Verseveld, H. W. (2002) entitled "Potential Nitrification and Factors Influencing Nitrification in Pine Forest and Agricultural Soil in Central Java, Indonesia“, aimed to determine the potential level of nitrification and the factors that can influence nitrification control in pine tropical forests and agricultural soils in Central Java, Indonesia.

A study by Purwanto, E.Handayanto, D. Suprayogo, dan K. Hairiah. (2006) entitled "Impact of forest conversion into coffee agroforestry on nitrification rates: population inventory and activities of nitrifying bacteria“, aimed to determine the effect of various types of legume shade trees on coffee-based agroforestry systems on soil $\mathrm{N}$ 
$\left(\mathrm{NH}_{4}{ }^{+}\right.$and $\left.\mathrm{NO}_{3}^{-}\right)$concentrations and soil potential nitrification, and to assess the controlling factors for the occurrence of nitrification in the field.

A study by Li, J., Shi, Y., Luo, J., Zaman, M., Houlbrooke, D., Ding, W., Ghani, A. (2014) entitled "The Use of Nitrogen Process Inhibitors for Reducing Gaseous Nitrogen Losses from Land-applied Farm Effluents", aimed to evaluate the potential of NBTPT or DCD in reducing $\mathrm{NH}_{3}$ and $\mathrm{N}_{2} \mathrm{O}$ gas emissions, respectively, from the application of various types of waste.

A study by Roviqowati, F., Purwanto, P., \& Hartati, S. (2015) entitled "Vertisols N-Mineral Dynamics In Several Litter Quality Combination and N-Sweet Corn Uptake", aimed to study the potential of soil N loss through various nitrification control treatments, determine the combination of quantity and quality (lignin content, polyphenols, and $\mathrm{C} / \mathrm{N}$ ) optimum litter to control nitrification in the study area, assess the effect of dosage, litter quality and its role on $\mathrm{N}$ uptake sweet corn.

A study by Dall'Orsoletta, D. J., Rauber, L. P., Schmitt, D. E., Gatiboni, L. C., \& Orsolin, J. (2017) entitled "Urea Coated with Poultry Litter As An Option in The Control of Nitrogen Losses", aimed to the evaluate N losses by $\mathrm{NH}_{3}$ volatilization and mineral $\mathrm{N}$ transformation in the soil with urea coated with poultry litter (urea + litter) compared with other sources of N, under two moisture conditions.

\subsection{What Distinguishes this Study from Previous Studies}

This study examines the effect of adding local litter to the dynamics of ammonium, nitrate, and nitrification potential as supporting factors in determining the level of efficiency of $\mathrm{N}$ utilization by corn plants to vegetative times, taking into account the nature of the Andisols.

\section{Materials and Methods}

\subsection{Experimental Site and Soil Properties}

The experiment was carried out in a plastic greenhouse located in Plesungan, Karanganyar, Central Java Province around May-June by using a randomized complete design with three replications. The average air temperature at the experimental site was $21.9^{\circ} \mathrm{C}$, and humidity was $86.6 \%$. Andisol soil media was taken from Tegalrejo, Semarang, Central Java Province $07^{\circ} 25$ '28.3" S and $110^{\circ} 31$ '35.7" E with an altitude of 760 meters above sea level. There are 5 treatments involved: one control and four natural inhibitor treatments in the form of litter addition. The litter used was Gliricidia maculate, Albizzia falcataria, Senna siamea, and Tithonia diversifolia.

Table 1. Results of initial soil analysis before treatment

\begin{tabular}{ccc}
\hline Variable & Result & Grade \\
\hline $\mathrm{pH} \mathrm{H} \mathrm{H}_{2} \mathrm{O}$ & 6.5 & Rather sour* \\
$\mathrm{pH} \mathrm{NaF}$ & 10.3 & - \\
$\mathrm{N}$ total & $0.42 \%$ & Middle * \\
$\mathrm{C}$ organic & $2.36 \%$ & Middle * \\
$\mathrm{C} / \mathrm{N}$ & $5.62 \%$ & Low*
\end{tabular}

Table 2. The results of the analysis of the chemical properties of litter

\begin{tabular}{cccccc}
\hline \multirow{6}{*}{$\begin{array}{c}\text { Chpe of litter } \\
\text { Value } \\
\text { of } C / N\end{array}$} & Lignin (\%) & $\begin{array}{c}\text { Polyphenol } \\
\text { \%) }\end{array}$ & $\begin{array}{c}\text { Value of } \\
(L+P) / N\end{array}$ & Grade \\
\hline Gliricidia maculate & 10 & 20.02 & 9.24 & 7.33 & High \\
Albizzia falcataria & 7 & 30.10 & 15.11 & 9 & High \\
Senna siamea & 16.95 & 16.1 & 1.87 & 6.83 & High \\
Tithonia diversifolia & 18.75 & 20.84 & 4.37 & 18.35 & Low \\
\hline
\end{tabular}

\subsection{Crop Management and Treatments}

The experiment was carried out in a plastic greenhouse. The plastic greenhouse used in the experiment was $10 \mathrm{~m}$ long, $4 \mathrm{~m}$ wide, $3 \mathrm{~m}$ high and headed north-south. The pot used is $35 \mathrm{~cm}$ in diameter, with a soil volume of $10 \mathrm{~kg}$. On May 22, incubation was carried out on soil mixed with manure at a dose of 200 tons/ha. During incubation 
until the 6th-day planting of corn seeds, basic fertilizers in the form of $\mathrm{ZA}$ fertilizer ( $\mathrm{N}$ fertilizer), $\mathrm{KCl}$ ( $\mathrm{K}$ fertilizer), and SP36 (P fertilizer) as well as the addition of litter according to treatment with a dose of 5.625 $\mathrm{Mg} /$ ha respectively or equivalent to $28.125 \mathrm{~g} /$ pot. Litter added is litter that has been dried and mashed with a size of $0.5 \mathrm{~mm}$. ZA fertilizer is given as much as $200 \mathrm{~kg} / \mathrm{ha}$ or equal to $0.9 \mathrm{~g} / \mathrm{pot}, \mathrm{KCl}$ fertilizer as much as 60 $\mathrm{kg} / \mathrm{ha}$ or equivalent to $0.5 \mathrm{~g} /$ pot, and SP36 fertilizer as much as $50 \mathrm{~kg} / \mathrm{ha}$ or equivalent to $0.735 \mathrm{~g} / \mathrm{pot}$. Fertilization with basic fertilizers in the form of $\mathrm{KCl}$ and SP36 is done 2 times, namely at the beginning of planting and vegetative periods, while ZA fertilizer is only given 1 time at the beginning of planting. Watering plants once a day in the afternoon, as much as $300 \mathrm{ml}$ for each plant. Weed cleaning is done once a week.

\subsection{Measurements}

Soil samples used for the analysis of the parameters in Table 1 were taken from each pot with a depth of 0-20 cm. Those samples were then put into iceboxes to keep them fresh and make the bacteria in the soil samples temporarily inactive. The parameters analysis for the fresh soil were ammonium, potential nitrification, and nitrate. The other parameter used a soil sample that has been dried and pulverized into a size of $0.5 \mathrm{~mm}$. Soil samples were taken once every 6 days. Ammonium analysis, potential nitrification, and nitrate were carried out at the same time as the day of sampling, aimed at maintaining soil freshness, while for other parameters waiting for the soil to be drained.

The potential nitrification is obtained from the amount of $\mathrm{NO}_{2}^{-}$formed from soil samples after adding $\left(\mathrm{NH}_{4}\right)_{2} \mathrm{SO}_{4}$ and incubated at $25^{\circ} \mathrm{C}$ for 5 hours. The formed nitrite was extracted with $\mathrm{KCl}$ and arranged colorimetrically at $\lambda$ $520 \mathrm{~nm}$. The oxidation process of $\mathrm{NO}_{2}{ }^{-}$to $\mathrm{NO}_{3}{ }^{-}$during incubation is inhibited through $\mathrm{NaClO}_{3}$ (Robinson, Schinner, Ohlinger, Kandeler, \& Margesin, 2006). The calculation used the following formula:

$$
\frac{(S-C) \cdot 25 \cdot 1 \cdot 1000 \cdot 100}{5.5 \% d m}=n g N \cdot \frac{1}{g} d m \cdot h / 5
$$

Ammonium in the soil can be measured directly by colorimetry by the Indofenol Blue method, while nitrates in the soil can be measured spectrophotometrically by brucine dye reagents (BPT, 2009).

Measurement of plant parameters in the form of plant height, number of leaves, root weight, and stover weight was carried out at harvest (maximum vegetative period). Specifically for root and stover weight parameters, what is used is the weight of the roots and stover that have dried (Beethoven). The roots and stover are roasted at $80^{\circ} \mathrm{C}$ for 24 hours. Measuring supporting parameters such as soil temperature, air temperature, soil humidity, and air humidity is done every 6 days, together with the time of soil sampling.

\subsection{Statistical Analysis}

One way ANOVA was performed to determine the significance of treatment for potential nitrification with SPSS Statistics 23. The significance of the treatment and their interactions were estimated using the F-test, and the least significant difference (LSD) was used to compare means at the 0.05 level.

\section{Result}

\subsection{Ammonium and Local Litter}

Ammonium is analyzed every 6 days for 30 days, resulting in 6 measurements. As discussed in Figure 1, for 30 days the ammonium in the soil dynamics transition. Ammonium produced on day 0 of the lowest treatment occurred in the control, namely $1.33 \mathrm{mg} \mathrm{N} \mathrm{kg} \mathrm{soil}{ }^{-1}$, while the most occurred in processing supported by litter Tithonia diversifolia which was $3.95 \mathrm{mg} \mathrm{N} \mathrm{kg} \mathrm{soil}{ }^{-1}$. At the end of monitoring time (day 30), ammonium on all examinations decreased repair. Average of the highest yield of ammonium concentrations for 30 days occur in the treatment of Tithonia diversifolia which was $1.31 \mathrm{mg} \mathrm{N} \mathrm{kg} \mathrm{soil}^{-1}$ and the lowest occurs in the control

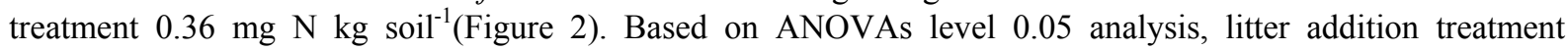
significantly affect ammonium concentrations in the soil $(p=0.159)$. 


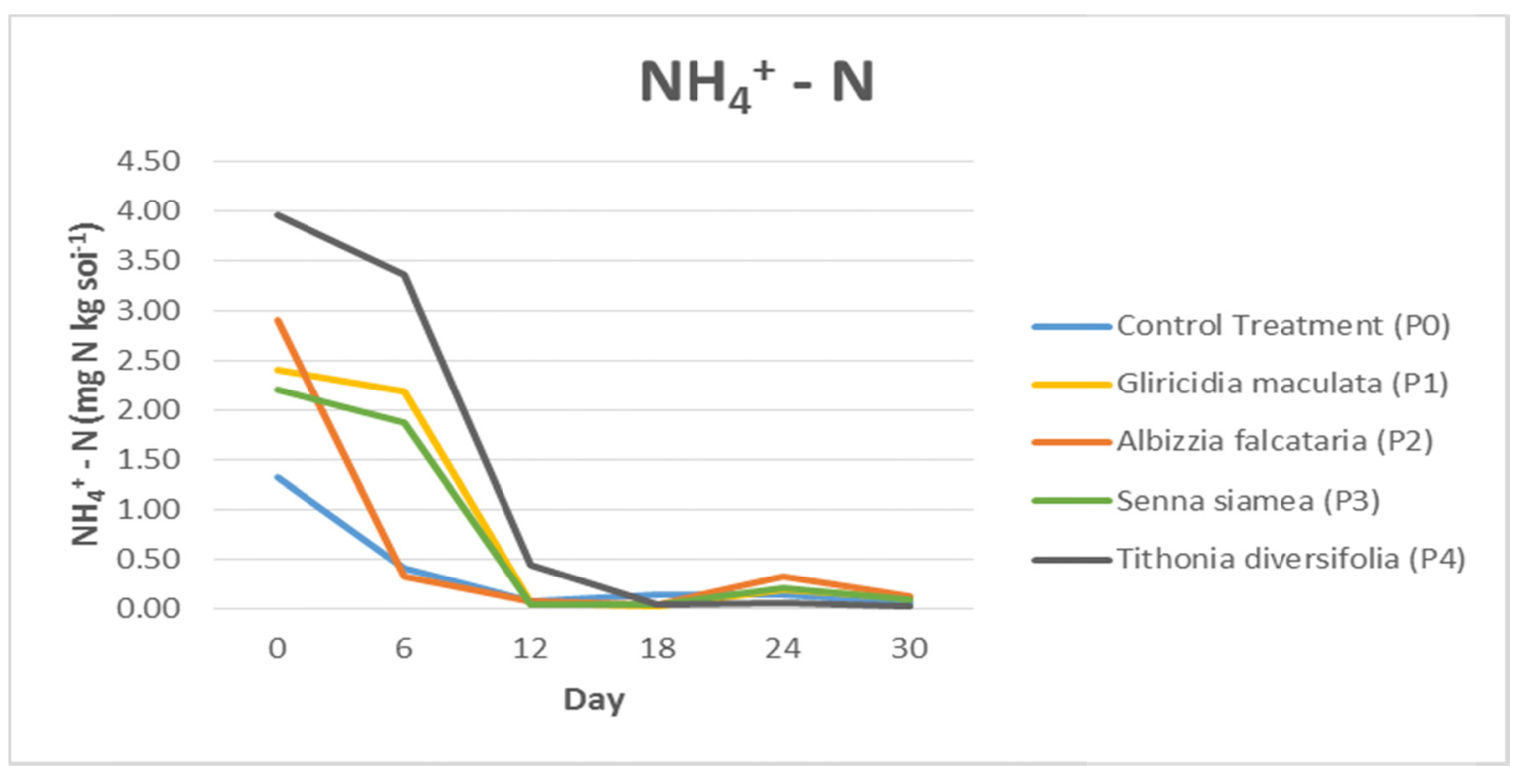

Figure 1. Relationship of treatment with ammonium dynamics in soil

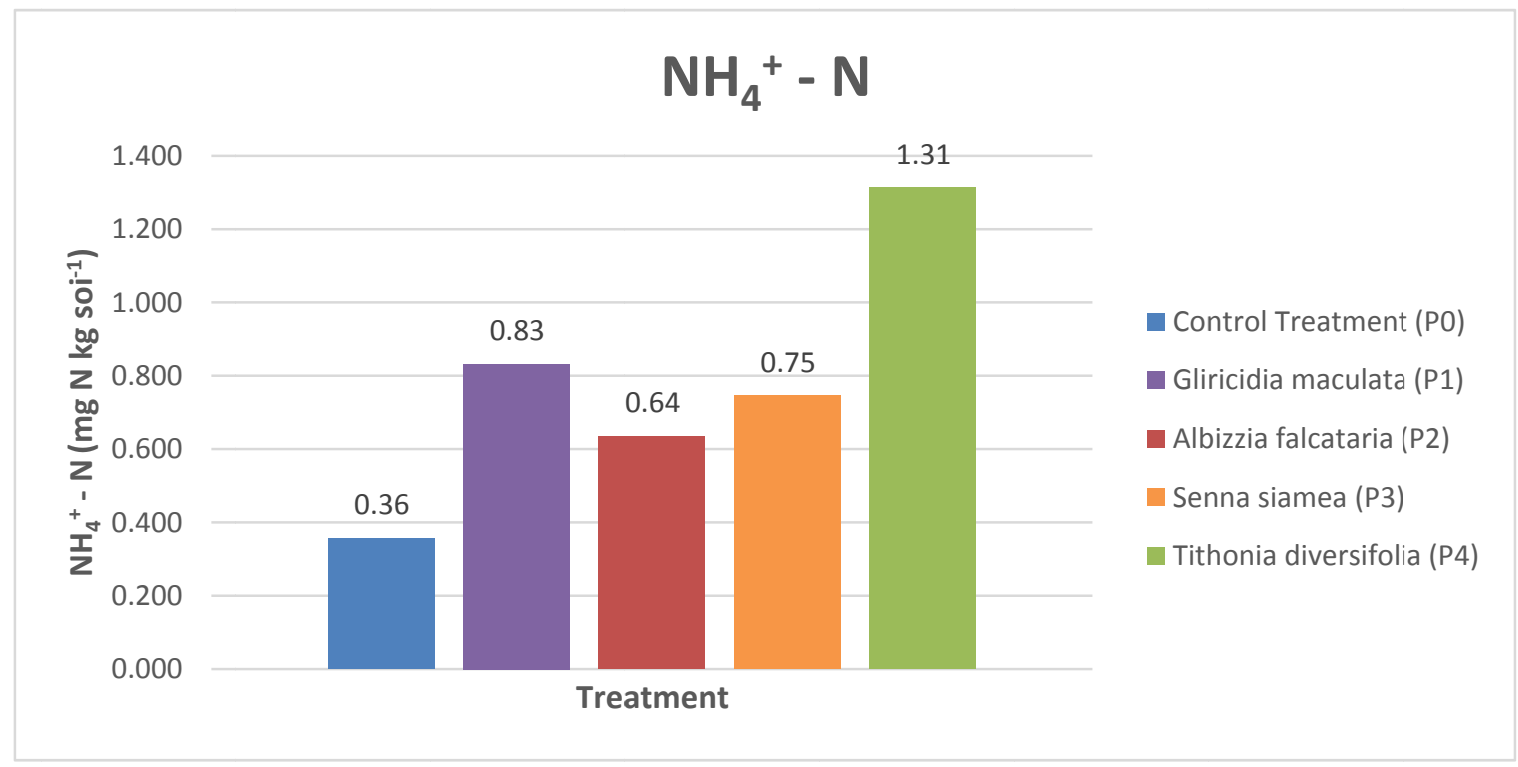

Figure 2. The average ammonium in the soil for an incubation period of 30 days

\subsection{Nitrite and Local Litter}

Nitrite or also called potential nitrification analysis is carried out in the same as ammonium. The analysis was every 6 days for 30 days, so 6 results were obtained from the measurements. It is shown in Figure 3 that the nitrite dynamics in the soil between control and treatment are different. The dynamics of the control treatment is more stable than the treatment. In the analysis results, it is known that the highest nitrite content on day 0 occurred in the addition of control treatment of $60.58 \mathrm{mg} \mathrm{N} \mathrm{kg} \mathrm{soil}^{-1}$, and the lowest nitrite concentrations occurred in the addition of Tithonia diversifolia litter amounting to $8.82 \mathrm{mg} \mathrm{N} \mathrm{kg} \mathrm{soil}^{-1}$. The analysis results show that the highest nitrite concentrations on the 30th-day incubation occurred with the addition of Tithonia diversifolia litter of $9.64 \mathrm{mg} \mathrm{N} \mathrm{kg} \mathrm{soil}^{-1}$ and the lowest nitrite concentrations occurred in the control treatment of $5.56 \mathrm{mg} \mathrm{N} \mathrm{kg} \mathrm{soil}{ }^{-1}$. While on average for 30 days the highest nitrite concentrations occurred in the treatment of Gliricidia maculata litter addition of $126.77 \mathrm{mg} \mathrm{N} \mathrm{kg} \mathrm{soil}^{-1}$ and the lowest occurred in the control treatment of $52.20 \mathrm{mg} \mathrm{N} \mathrm{kg} \mathrm{soil}{ }^{-1}$ (Figure 4). Based on ANOVAs analysis at 0.05 level, litter addition treatment significantly affect nitrite concentrations in the soil $(p=0.041)$. 


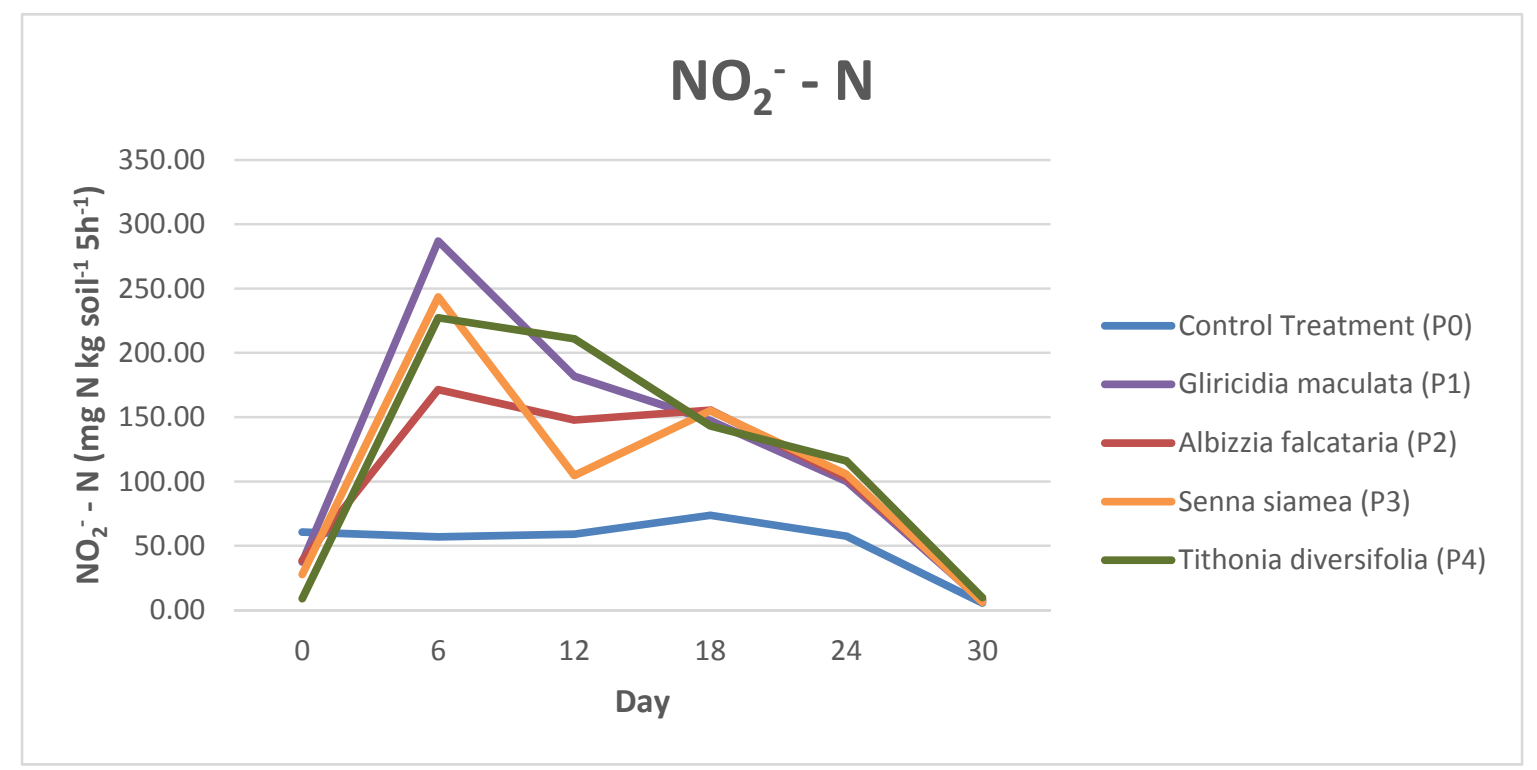

Figure 3. Relationship of treatment with nitrite in the soil

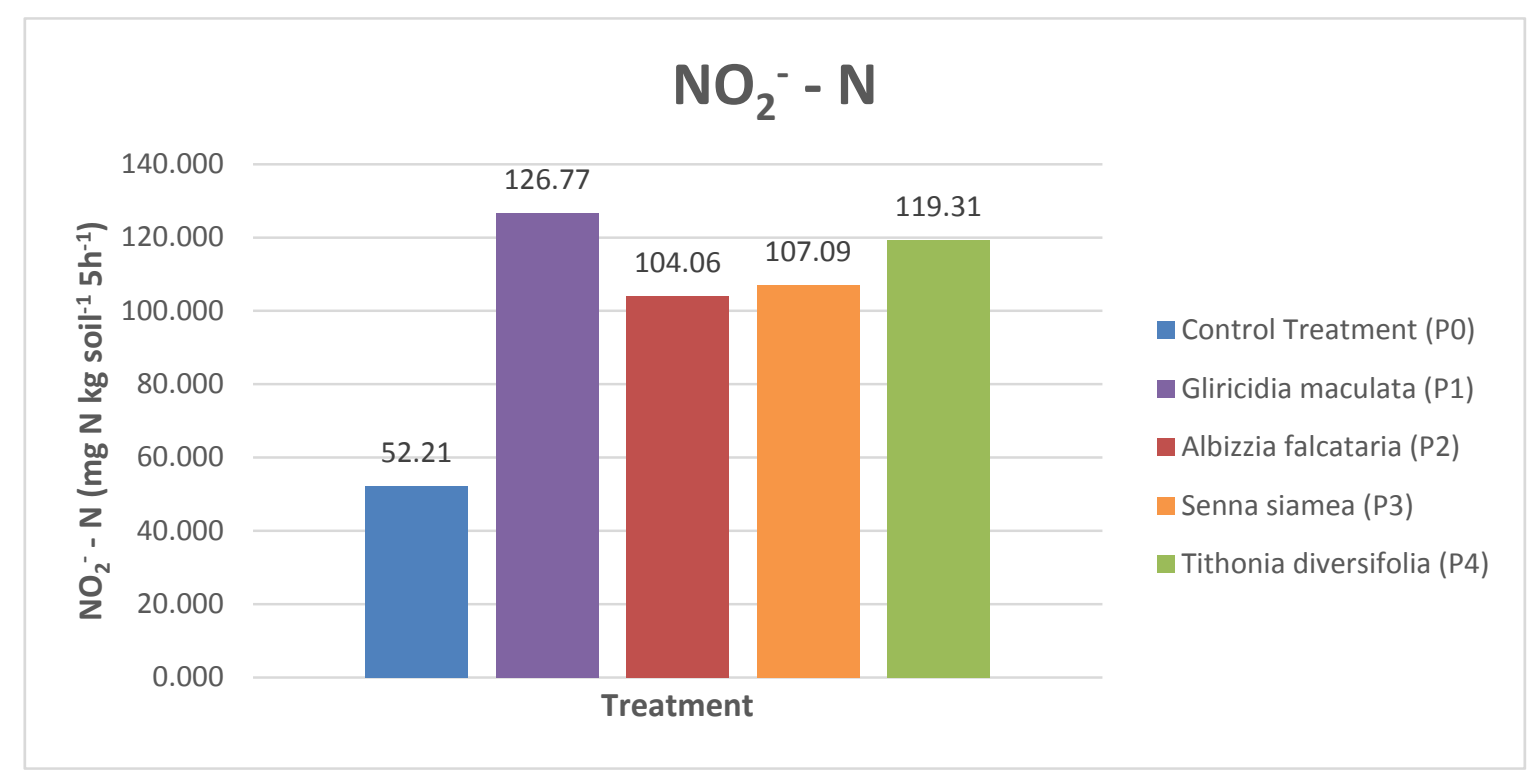

Figure 4 . The average nitrite in the soil for an incubation period of 30 days

\subsection{Nitrate and Local Litter}

Nitrate analysis is carried out such as ammonium and nitrite analysis. Analyzed every 6 days for 30 days, so get 6 results from measurements. It is shown in Figure 5 that the dynamics of nitrate patterns in the soil between controls and treatments are almost the same. In the results of incubation analysis on day 0 , it was found that the highest nitrate concentrations in the control treatment was $0.67 \mathrm{mg} \mathrm{N} \mathrm{kg} \mathrm{soil}{ }^{-1}$ and the lowest nitrate concentrations in the Albizzia falcataria treatment was $0.22 \mathrm{mg} \mathrm{N} \mathrm{kg} \mathrm{soil}{ }^{-1}$. In the results of the 30th-day incubation analysis, the highest nitrate concentrations in the Senna siamea treatment was $2.55 \mathrm{mg} \mathrm{N} \mathrm{kg} \mathrm{soil}{ }^{-1}$ and the lowest nitrate concentrations in the control treatment was $1.44 \mathrm{mg} \mathrm{N} \mathrm{kg} \mathrm{soil}^{-1}$. Meanwhile, on average for 30 days, the highest nitrate concentrations occurred in the treatment of Tithonia diversifolia litter addition of 2.69 $\mathrm{mg} \mathrm{N} \mathrm{kg} \mathrm{soil}{ }^{-1}$ and the lowest occurred in the control treatment of $1.69 \mathrm{mg} \mathrm{N} \mathrm{kg} \mathrm{soil}{ }^{-1}$ (Figure 6). Based on ANOVAs analysis at 0.05 level, litter addition treatment did not significantly affect nitrate concentrations in the soil $(p=0.221)$. 


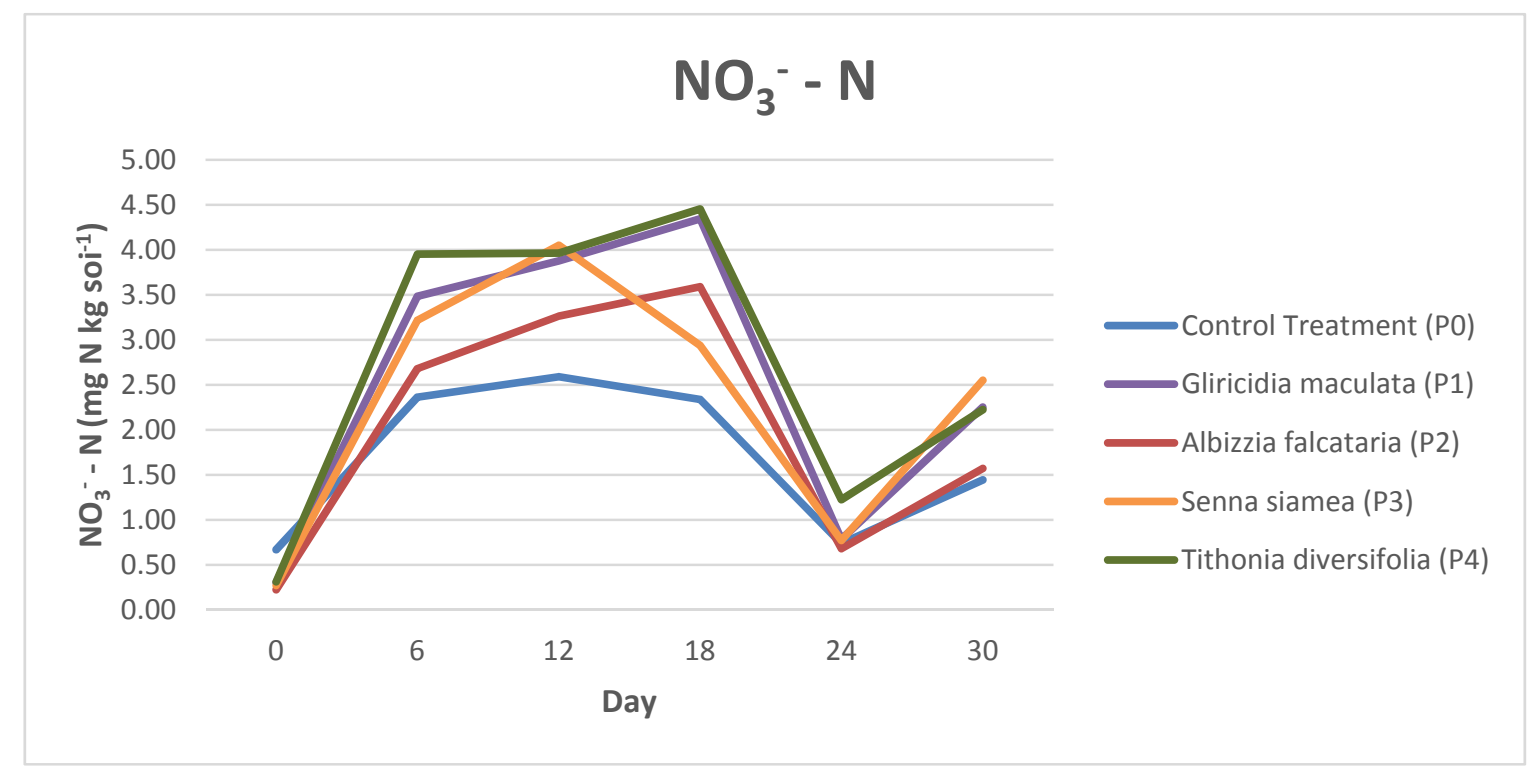

Figure 5. Relationship of the treatment with the dynamics of nitrate in the soil

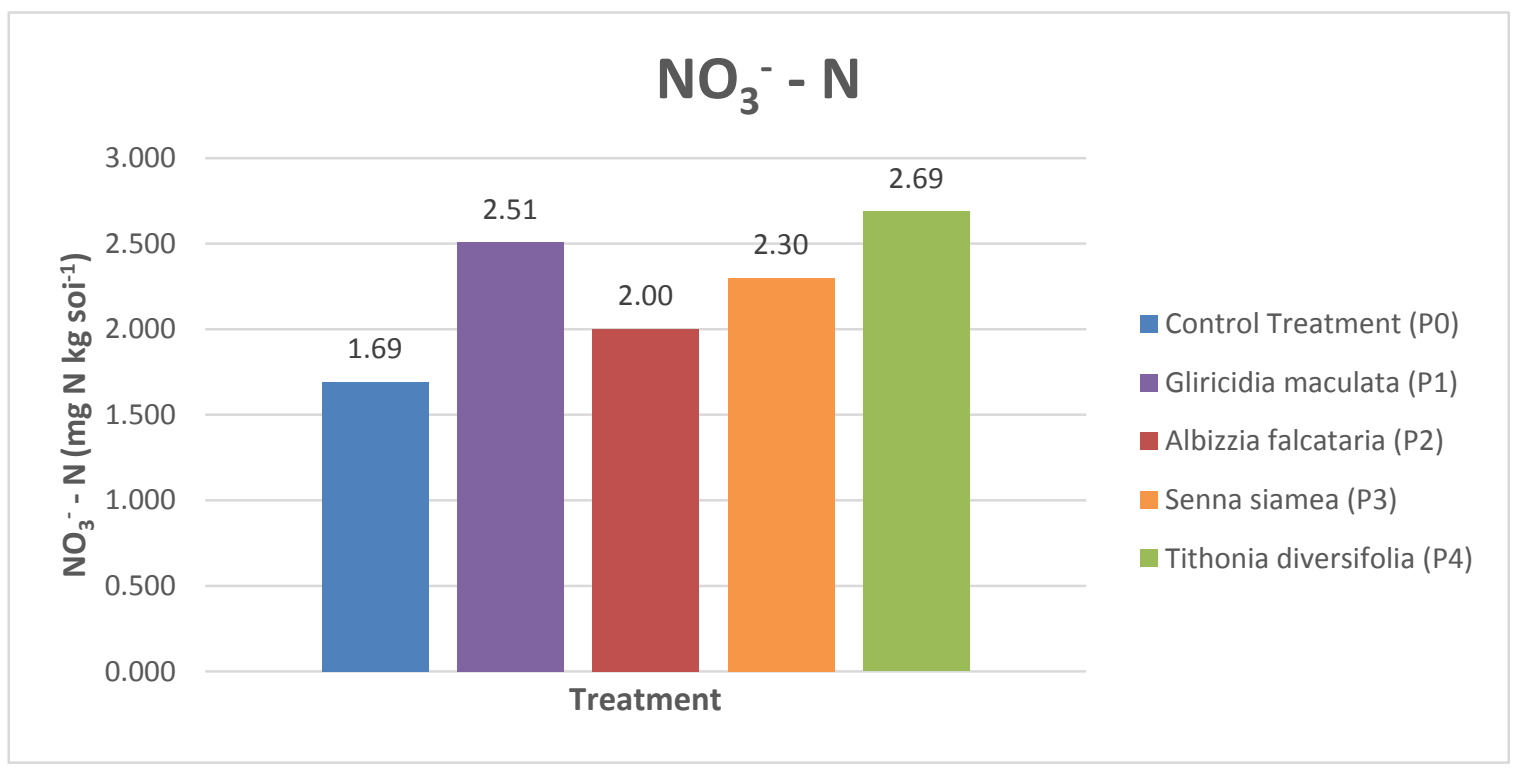

Figure 6. The average nitrate in the soil for an incubation period of 30 days

\subsection{The Efficiency of $N$ Utilization with Local Litter}

The Efficiency Utilization of $\mathrm{N}$ obtained from $\mathrm{NH}_{4}{ }^{+} / \mathrm{N}$-minerals shows that in incubation day 0 , the highest result was in the Albizzia falcataria treatment (92.55\%) and the lowest was in the control treatment (66.72\%). The highest efficiency of $\mathrm{N}$ utilization on the 30th-day incubation in the Albizzia falcataria treatment was 7.62\% and the lowest was on the Tithonia diversifolia treatment $0.86 \%$ (Figure 7). Meanwhile, the highest average efficiency of $\mathrm{N}$ utilization for 30 days occurred in the addition of Tithonia diversifolia litter treatment at $25.79 \%$ and the lowest occurred in the control treatment at $18.16 \%$ (Figure 8). The graphic pattern of the efficiency of $\mathrm{N}$ utilization observed for 30 days between control and treatment has a similar decreasing pattern, but increasing on incubation day 24. Based on the ANOVAs analysis at a level of 0.05 , litter addition treatment did not significantly affect the efficiency of $\mathrm{N}$ utilization $(p=0.942)$. 


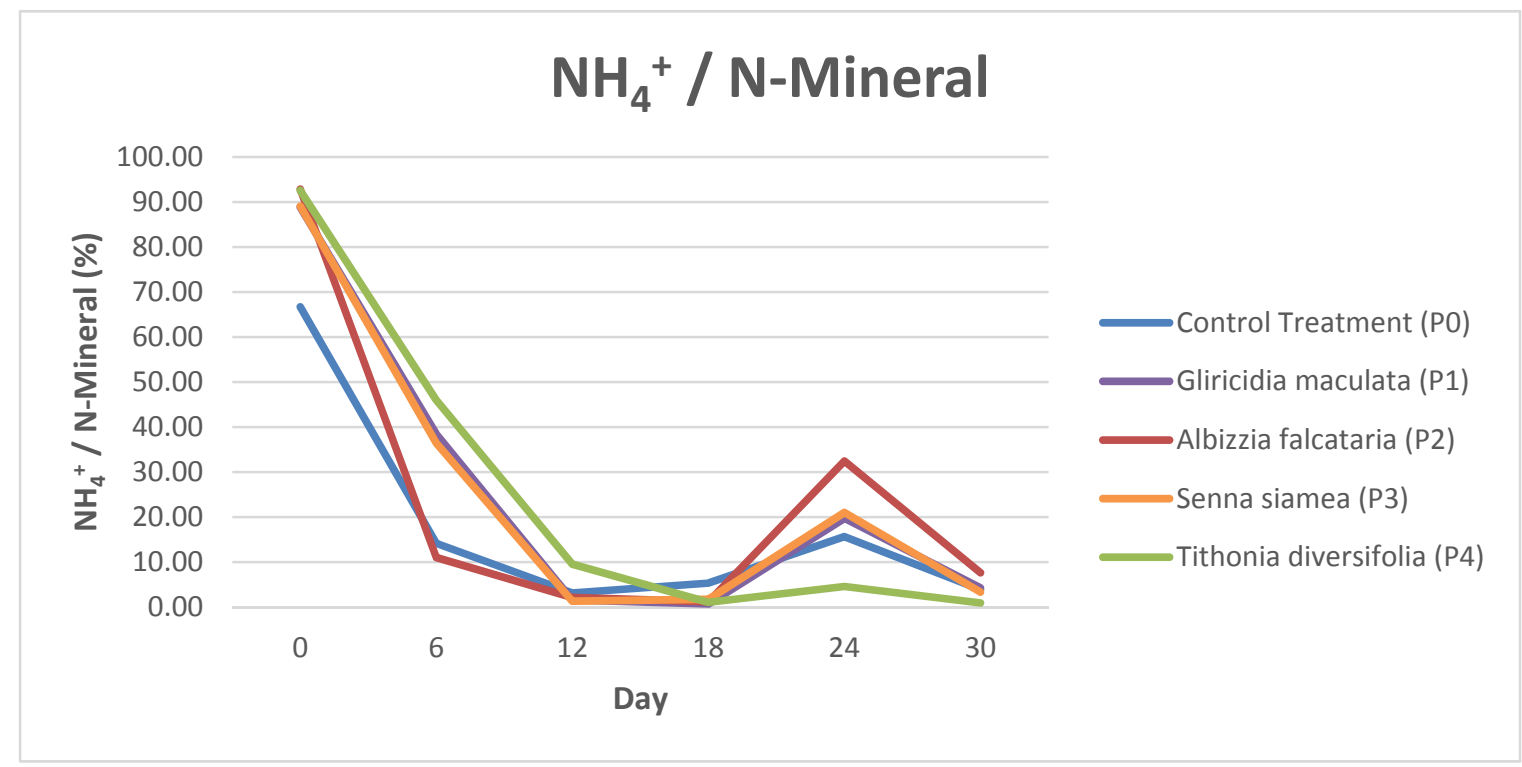

Figure 7. The relationship of treatment with the utilization efficiency of $\mathrm{N}$

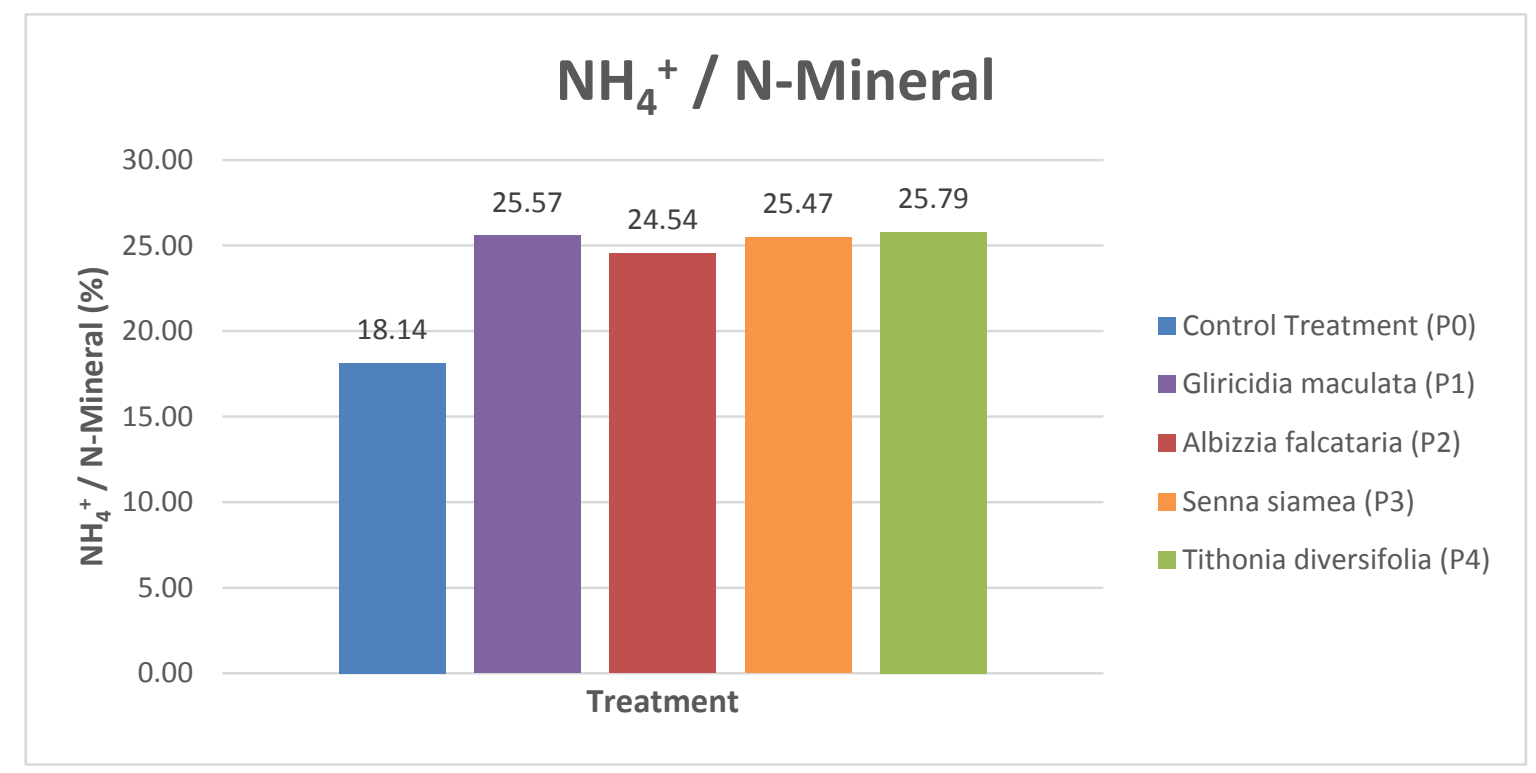

Figure 8 . The average utilization efficiency of $\mathrm{N}$ for an incubation period of 30 days

\subsection{Plant Growth}

The results of the ANOVAs test level of 0.05 showed that the treatment did not a significant effect on plant growth; root dry weight $(p=0.110)$, canopy dry weight $(p=0.152)$, plant height $(p=0.898)$ and the number of leaves $(p=0.951)$. Table 3 shows that the results of measurements of the plant's height, number of leaves and root's dry weight are not greatly different between control and treatment. It is unlike the case with the results of measurements of canopy's dry weight, which shows a fairly clear difference. The greatest root's dry weight in the treatment of adding Tithonia diversifolia litter was $5.81 \mathrm{~g}$ and the least in the control treatment was $4.40 \mathrm{~g}$. The greatest canopy's dry weight in the treatment of adding Tithonia diversifolia litter was $36.21 \mathrm{~g}$ and the least in the control treatment was $27.12 \mathrm{~g}$. Based on the correlation test, the dry weight of the root is positively correlated with ammonium $(p=0.030, r=0.559)$ and the efficiency of the utilization of $\mathrm{N}(p=0.032, r=0.555)$. The dry weight of the canopy is positively correlated with ammonium $(p=0.007, r=0.666)$ and is negatively correlated with the potential of nitrification $(p=0.044, r=-0.527)$. The height of the plant is negatively correlated with ammonium $(p=0.000, r=-0.731)$ and potential nitrification $(p=0.000, r=-0.725)$. The number of leaves is negatively correlated with ammonium $(p=0.000, r=-0696)$ and the utilization efficiency of $\mathrm{N}(p=0.000$, $r=-0.660)$. 
Table 3. Effect of Treatment on Growth of Corn Plants

\begin{tabular}{ccccc}
\hline Treatment & \multicolumn{4}{c}{ Parameter } \\
Plant Height $(\mathrm{cm})$ & $\begin{array}{c}\text { Number of } \\
\text { Leaves }\end{array}$ & $\begin{array}{c}\text { Root Dry } \\
\text { Weight }(\mathrm{g})\end{array}$ & $\begin{array}{c}\text { Canopy Dry } \\
\text { Weight }(\mathrm{g})\end{array}$ \\
\hline Control treatment & $135^{\mathrm{ns}}$ & $11^{\mathrm{ns}}$ & $4.40^{\mathrm{ns}}$ & $27.12^{\mathrm{ns}}$ \\
Gliricidia maculate & $128^{\mathrm{ns}}$ & $11^{\mathrm{ns}}$ & $5.50^{\mathrm{ns}}$ & $31.90^{\mathrm{ns}}$ \\
Albizzia falcataria & $130^{\mathrm{ns}}$ & $12^{\mathrm{ns}}$ & $5.28^{\mathrm{ns}}$ & $31.22^{\mathrm{ns}}$ \\
Senna siamea & $134^{\mathrm{ns}}$ & $11^{\mathrm{ns}}$ & $5.58^{\mathrm{ns}}$ & $28.14^{\mathrm{ns}}$ \\
Tithonia diversifolia & $134^{\mathrm{ns}}$ & $13^{\mathrm{ns}}$ & $5.81^{\mathrm{ns}}$ & $36.21^{\mathrm{ns}}$ \\
\hline
\end{tabular}

Notes : $\mathrm{ns}=$ non significant

3.6 Soil pH, $N$ Total, C Organic, and C/N Ratio

Soil $\mathrm{pH}$, total $\mathrm{N}, \mathrm{C}$-organic, and $\mathrm{C} / \mathrm{N}$ ratio are the supporting parameters that are considered to influence the main soil parameters (ammonium concentrations, nitrate, and nitrite) and also the efficiency of $\mathrm{N}$ utilization. Table 4 shows that the highest average of soil $\mathrm{pH}$ occurs in the Gliricidia maculata treatment 7.34 and lowest in the Tithonia diversifolia treatment 6.42. The highest total $\mathrm{N}$ level was in the control treatment with a score of $0.49 \%$ and the lowest was in the Senna siamea treatment with a score of $0.41 \%$. The highest levels of C-organic occurred in the Albizzia falcataria treatment $1.64 \%$ and the lowest occurred in the Senna siamea $1.33 \%$ treatment. while the highest $\mathrm{C} / \mathrm{N}$ ratio occurs in the Albizzia falcataria 4.78 treatment and the lowest occurs in the control treatment 3.45 treatment. Based on the results of ANOVAs test level 0.05 the treatment significantly affects the $\mathrm{C}$-Organic and $\mathrm{pH} \mathrm{H}_{2} \mathrm{O}$. However, it did not significantly affect the $\mathrm{N}$-Total and $\mathrm{C} / \mathrm{N}$ ratio. However, based on the correlation test, it is found that several supporting parameters correlate with the main parameters. Total $\mathrm{N}$ positively correlated with ammonium concentrations $(p=0.016, r=0.253)$ and efficiency of $\mathrm{N}$ utilization $(p=0.007, r=0.284)$.

Table 4. Average results of the analysis of soil $\mathrm{pH}, \mathrm{N}$ total, $\mathrm{C}$ organic, and $\mathrm{C} / \mathrm{N}$ ratio

\begin{tabular}{ccccc}
\hline \multirow{2}{*}{ Treatment } & \multicolumn{4}{c}{ Parameter } \\
& $\mathrm{HH} \mathrm{H}_{2} \mathrm{O}$ & N total (\%) & $\begin{array}{c}\text { Corganic } \\
(\%)\end{array}$ & C/N ratio \\
\hline Control treatment & 6.70 & 0.49 & 1.53 & 3.45 \\
Gliricidia maculate & 7.34 & 0.45 & 1.59 & 4.34 \\
Albizzia falcataria & 7.16 & 0.48 & 1.64 & 4.78 \\
Senna siamea & 7.25 & 0.41 & 1.33 & 3.77 \\
Tithonia diversifolia & 6.42 & 0.45 & 1.58 & 4.00 \\
\hline
\end{tabular}

\section{Discussion}

The results of laboratory analysis indicate that there are dynamics of the $\mathrm{NH}_{4}^{+}, \mathrm{NO}_{2}{ }^{-}$(potential nitrification), and $\mathrm{NO}_{3}{ }^{-}$concentrations in the soil. The treatment gives almost the same effect on the dynamic pattern of N-mineral concentrations in the soil, both $\mathrm{NH}_{4}{ }^{+}, \mathrm{NO}_{2}{ }^{-}$, and $\mathrm{NO}_{3}{ }^{-}$, except in the control treatment which shows a slightly different pattern. In the control treatment, the $\mathrm{NH}_{4}^{+}$concentrations in the soil at 0 HST was lower than the other treatments. Thus, the potential nitrification of $\mathrm{NO}_{2}{ }^{-}$and $\mathrm{NO}_{3}{ }^{-}$is also lower compared to other treatments. Also, because there is no addition of litter, the $\mathrm{NH}_{4}{ }^{+}$obtained from fertilizer in the control treatment is directly assimilated by plants so that the concentrations in the soil is low.

The results of laboratory analysis also show that with the addition of Tithonia diversifolia litter, the average efficiency of $\mathrm{N}$ utilization is high, although the results of statistical analysis show that the treatment did not significantly affect the efficient utilization of $\mathrm{N}$. The treatment just significantly affect the potential nitrification. Tithonia diversifolia seen from the lignin content, polyphenols, $\mathrm{C} / \mathrm{N}$ ratio, as well as the ratio of the amount of lignin and polyphenols with nitrogen $(\mathrm{L}+\mathrm{P} / \mathrm{N})$ categorized as litter with low quality (Table 2). According to Handayanto, Cadisch, \& Giller (1995); Purwanto (2006), the most influential litter quality factor to the release of $\mathrm{NH}_{4}{ }^{+}$and $\mathrm{NO}_{3}{ }^{-}$formation (nitrification) of soil are the ratio of litter (polyphenol+lignin)/ $\mathrm{N}$ litter, when compared to the content of lignin, polyphenols or $\mathrm{C} / \mathrm{N}$ ratio. Litter is said to be of high quality when the $\mathrm{C} / \mathrm{N}$ content $<25$, polyphenol content $<3 \%$ and lignin content $<15 \%$ or ratio (lignin + polyphenol) $/ \mathrm{N}<10$ (Palm \& Sanchez, 1991). 
The addition of low-quality litter can slow down the formation of $\mathrm{NH}_{4}{ }^{+}$in the soil because it produces a lower $\mathrm{NH}_{4}{ }^{+}$concentration ratio so that it can control the nitrification process in the soil. The lower $\mathrm{NH}_{4}{ }^{+}$concentration ratio is considered to be caused by the added litter that slowly decomposes so that it can gradually be available in the soil (Roviqowati, Purwanto, \& Hartati, 2015). The treatment of adding low-quality litter will inhibit the rate of decomposition because the high levels of polyphenols will cause high inhibitory effectiveness. This is following previous research (Brady \& Weil, 2004) which stated that litter with high phenol or lignin content with $\mathrm{N}$ release which is slow will benefit in the long term because $\mathrm{N}$ mineralization results will be free from leaching. The treatment did not significantly affect the nitrification potential or the level of efficiency of $\mathrm{N}$ utilization supposedly due to environmental factors, such as soil conditions, air temperatures, soil $\mathrm{pH}$, and soil moisture. According to Allen et al., 2005; K. L. Sahrawat (2008); Verstraete \& Focht (1977), some of the environmental factors that affect nitrification in the soil are aeration (oxygen), temperature, humidity, ammonium ion abundance, density and diversity of nitrification, and substrate for nitrifier is the most important.

Giving high $\mathrm{C} / \mathrm{N}$ litter into the soil indirectly can inhibit nitrification because $\mathrm{NH}_{4}{ }^{+}$results from litter mineralization and $\mathrm{NH}_{4}{ }^{+}$in the soil will be immobilized by heterotroph microbial short litter composition so that the litter does not leave $\mathrm{NH}_{4}{ }^{+}$to be nitrified. After the litter decomposes and the $\mathrm{C} / \mathrm{N}$ ratio decreases, the partially immobilized $\mathrm{N}$ will be mineralized so that $\mathrm{NH}_{4}{ }^{+}$is available again as a nitrification substrate. Therefore, the $\mathrm{C} / \mathrm{N}$ BOT ratio can be a nitrification regulator and $\mathrm{NO}_{3}{ }^{-}$concentration in the soil (Mancinelli \& McKay, 1988; Paul \& Clark, 1988). The addition of litter can suppress $\mathrm{NO}_{3}{ }^{-}$concentration in the soil, but not because it inhibits the nitrification process, but because of the competition for the use of $\mathrm{NH}_{4}{ }^{+}$and $\mathrm{NO}_{3}{ }^{-}$by heterotrophic microbes when decomposing litter (Myrold et al., 2008). Nitrifying bacteria get their energy only from the oxidation of $\mathrm{NH}_{4}{ }^{+}$to $\mathrm{NO}_{3}{ }^{-}$(Rosswall, 1982), the pattern of $\mathrm{NO}_{3}{ }^{-}$production can be attributed to the growth of nitrification populations originating from the soil (Nishio \& Fujimoto, 1990).

Based on the trial results, several supporting parameters correlate with the main parameters (ammonium, nitrate, and nitrite. Total $\mathrm{N}$ positively correlated with ammonium concentrations and the efficiency of $\mathrm{N}$ utilization. Some chemical parameters make it very easy to utilize nitrification in the soil. This was also conveyed by Bell, Tisdale, \& Nelson (1966); Gilliam, Yurish, \& Adams (2001); Kelly, Schoenholtz, \& Adams (2011); KL Sahorage (2008); Kanwar L. Sahorage (1996); Verstraete \& Focht (1977) that some soil chemical characters correlate with nitrification. Correlated include the $\mathrm{C} / \mathrm{N}$ ratio, $\mathrm{pH}$, soil moisture, and total $\mathrm{N}$.

Soil $\mathrm{pH}$ affects the nitrification because ammonium dioxide bacteria grow well at neutral to slightly alkaline $\mathrm{pH}$ condition. Although the statistic test is not correlated, it can be seen in the nitrate data and the $\mathrm{pH}$ of each treatment that the $\mathrm{pH}$ is more than 5 then the nitrate that is formed is increasingly greater. According to (K. L. Sahalagi, 2008) nitrification occurs in soil with a pH between $5.5-10$, and is optimal at 8.5. Ammonia dioxide bacteria decrease significantly at low $\mathrm{pH}$ and overflow at neutral or slightly alkaline $\mathrm{pH}$ (Yao et al., 2011). However, several studies have reported that nitrification can occur in acid soils with a pH of 3.8 (Bell et al., 1966). Nitrification can be suspected to occur in soils caused by the role of heterotrophic bacteria, although it is not apparent (De Boer \& Kowalchuk, 2001). Research conducted by (Kyveryga, Blackmer, Ellsworth, \& Isla, 2004) on the relationship between soil $\mathrm{pH}$ and nitrification for 4 years in corn plants in the United States shows how nitrification in soils with a $\mathrm{pH}$ of more than 7.5 is $89 \%$, whereas in soil with a pH of less than 6.0 is $39 \%$. It is possible that in the soil with a $\mathrm{pH}$ less than 5.0, there is a very limited nitrification process compared to soils that have a pH of more than 6.0 (Carlyle, Lowther, Smethurst, \& Nambiar, 1990; Kelly et al., 2011; KL Sahussalam, 2008; Ste - Marie \& Paré, 1999).

The total $\mathrm{N}$ in the soil positively correlated with ammonium and the efficiency of $\mathrm{N}\left(\mathrm{NH}_{4}{ }^{+} / \mathrm{N}\right.$-mineral $)$ utilization, supposedly because $\mathrm{N}$ in the soil is widely available in the form of $\mathrm{NH}_{4}{ }^{+}$. After all, the $\mathrm{pH}$ of the study soil is neutral to slightly alkaline so that ammonium dioxide bacteria are not much. This also causes a total $\mathrm{N}$ to be negatively correlated with nitrate. According to (Yao et al., 2011) nitrification potential positively correlated with total $\mathrm{N}$ and negatively correlated with $\mathrm{pH}$. Although research conducted by (Forest et al., 2010; Kelly et al., 2011) reported that total $\mathrm{N}$ soils were positively correlated with nitrate production for watershed soils that had been converted to soils planted with evergreen trees.

$\mathrm{C} / \mathrm{N}$ ratio in the soil according to Ross, Lawrence, \& Fredriksen (2004) has a negative correlation with nitrification. The lower the $\mathrm{C} / \mathrm{N}$ ratio, the higher the nitrification will be. On the contrary, according to Tietema, Emmett, Gundersen, Janne Kjønaas, \& Koopmans (1998), the C/N ratio indicates a high immobilization of $\mathrm{NH}_{4}{ }^{+}$ This is associated with the presence of a relatively large number of bacteria and fungi in soils that have a high $\mathrm{C} / \mathrm{N}$ ratio so that the release of $\mathrm{N}$ in inorganic form is higher. 
The results of observations of plant growth used as parameters consist of plant height, the number of leaves, root's dry weight, and canopy's dry weight. The results of statistical analysis showed that the treatment not significantly of all. But, the roots dry weight positively correlated with $\mathrm{NH}_{4}^{+}$concentrations and efficient utilization of $\mathrm{N}$. And also canopy dry weight positively correlated with $\mathrm{NH}_{4}^{+}$concentrations and efficient utilization of $\mathrm{N}$, negatively correlated with potential nitrification. It is a logical and true correlation. The greatest root's dry weight and shoot's dry weight were shown in the treatment of Tithonia diversifolia litter. This is in line with the results of laboratory analysis which also shows the highest utilization efficiency of $\mathrm{N}$ also occurs in the addition of Tithonia diversifolia litter treatment. According to Purwanto (2009), $\mathrm{NO}_{3}{ }^{-}$in the soil is formed due to the microbial oxidation process of $\mathrm{NH}_{4}{ }^{+}$. Therefore the $\mathrm{NH}_{4}{ }^{+} / \mathrm{N}-$ Mineral soil concentration ratio illustrates the actual nitrification of the soil. Total nitrogen in the soil is the amount between N-Minerals and N-Organic soils. N-Mineral/N-Total ratio of the soil will describe the number of $\mathrm{N}$ reserves that can be utilized by plants in the long run. The lower the concentration of $\mathrm{NH}_{4}{ }^{+} / \mathrm{N}$-mineral soil, the lower the ammonification process compared to nitrification formed in the soil. This means that the efficiency of $\mathrm{N}$ utilization in the soil will also be lower.

Research conducted by (Krave, Van Straalen, \& Van Verseveld, 2002) on some mountain soils showed that the soils contained litter pine. Out of 6 soil samples, only 2 of them had the availability of $\mathrm{NH}_{4}{ }^{+}$significantly affecting nitrification activity in the soil because there was a positive correlation with the number of MPN nitrification populations. Meanwhile, the other 4 soil samples did not show any significance between the availability of $\mathrm{NH}_{4}{ }^{+}$and $\mathrm{NO}_{3}{ }^{-}$. However, in the form of nitrification aliquots on artificial nitrification media, high nitrification occurs at the high availability of $\mathrm{NH}_{4}{ }^{+}$.

\section{Conclusion}

This study concludes that the addition of local litter has not been effective in controlling nitrification of corn plants in Andisols. This happened because the litter dose is given was not high enough, so that the statistical analysis did not significantly affect the main parameters in the form of $\mathrm{NH}_{4}{ }^{+}, \mathrm{NO}_{2}^{-}$(potential nitrification), $\mathrm{NO}_{3}{ }^{-}$, and $\mathrm{NH}_{4}{ }^{+} / \mathrm{N}$-mineral (efficiency of $\mathrm{N}$ utilization). However, the results of measurements in the field show that the addition of Tithonia diversifolia litter is enough to influence nitrification control. This is indicated by the existence of the highest $\mathrm{N}$ utilization efficiency Tithonia diversifolia treatment. The average efficiency of Tithonia diversifolia was $25.79 \%, 58.71 \%$ more efficient than the control treatment. It was also strengthened by the results of plant growth in the Tithonia diversifolia treatment for the parameters of dry weight and dry weight of the crown having the highest average. The root's dry weight and canopy dry weight positively correlated with concentrations $\mathrm{NH}_{4}{ }^{+}$and efficient utilization of $\mathrm{N}$. Besides, the dry weight of the canopy also has a negative correlation with the potential of nitrification. This research still requires soil samples that are only used in one place, it is necessary to do soil sampling with the same type but in different places. Also, further research needs to be conducted on the parameters involving microbial nitrification, leaching rate, and also the value of volatilized $\mathrm{N}$ to get more accurate results about the dynamics of $\mathrm{NH}_{4}^{+}, \mathrm{NO}_{2}^{-}$, and $\mathrm{NO}_{3}^{-}$in the soil caused by microbial processes because it is related to litter.

\section{Acknowledgment}

Financial support from this research was provided by the Ministry of Research, Technology and Higher Education, the Republic of Indonesia, and Sebelas Maret University, Surakarta. The authors sincerely want to dedicate this article to Prof. Ir. Supriyadi, M.P. and Prof. Ir. Purwanto, M.S. whose assistance is very important in advice, accommodation, and guidance. The reviewers sincerely praised their contribution to improving the text.

\section{References}

BBSLDP. (2014). Andosol land in Indonesia; characteristics, potential, constraints, and management for agriculture. Center for Research and Development of Agricultural Land Resources. ISBN 978-602-8977-84-5

Allen, S. C., Jose, S., Nair, P. K. R., Brecke, B. J., Nair, V. D., Graetz, D. A., \& Ramsey, C. L. (2005). Nitrogen mineralization in a pecan (Carya illinoensis K. Koch)-cotton (Gossypium hirsutum L.) alley cropping system in the southern United States. Biology and Fertility of Soils. https://doi.org/10.1007/s00374-004-0799-2

Bell, A. L., Tisdale, S. L., \& Nelson, W. L. (1966). Soil Fertility and Fertilizers. Journal of Range Management. https://doi.org/10.2307/3895409

BPT. (2009). Petunjuk Teknis Analisis Kimia Tanah, Tanaman, Air dan Pupuk. Balai Penelitian tanah. 
https://doi.org/10.1007/s13398-014-0173-7.2

Brady, N. C., \& Weil, R. R. (2004). Elements of the Nature and Properties of Soils. Journal of Chemical Information and Modeling. https://doi.org/10.1017/CBO9781107415324.004

Braker, G., \& Conrad, R. (2011). Diversity, structure, and size of N 2 O-producing microbial communities in soils-what matters for their functioning? Advances in Applied Microbiology. https://doi.org/10.1016/B978-0-12-387046-9.00002-5

Butterbach-Bahl, K., Baggs, E. M., Dannenmann, M., Kiese, R., \& Zechmeister-Boltenstern, S. (2013). Nitrous oxide emissions from soils: How well do we understand the processes and their controls? Philosophical Transactions of the Royal Society B: Biological Sciences. https://doi.org/10.1098/rstb.2013.0122

Byrnes, R. C., Nùñez, J., Arenas, L., Rao, I., Trujillo, C., Alvarez, C., \& Chirinda, N. (2017). Biological nitrification inhibition by Brachiaria grasses mitigates soil nitrous oxide emissions from bovine urine patches. Soil Biology and Biochemistry. https://doi.org/10.1016/j.soilbio.2016.12.029ttps://doi.org/10.1016/j.soilbio.2016.12.029

Cantarella, H., Trivelin, P. C. O., Contin, T. L. M., Dias, F. L. F., Rossetto, R., Marcelino, R., \& Quaggio, J. A. (2008). Ammonia volatilisation from urease inhibitor-treated urea applied to sugarcane trash blankets. Scientia Agricola. https://doi.org/10.1590/S0103-90162008000400011

Carlyle, J. C., Lowther, D. J. R., Smethurst, P. J., \& Nambiar, E. K. S. (1990). Influence of chemical properties on nitrogen mineralization and nitrification in podzolized sands. Implications for forest management. Australian Journal of Soil Research. https://doi.org/10.1071/SR9900981

Dall'Orsoletta, D. J., Rauber, L. P., Schmitt, D. E., Gatiboni, L. C., \& Orsolin, J. (2017). Urea coated with poultry litter as an option in the control of nitrogen losses. Revista Brasileira de Engenharia Agricola e Ambiental. https://doi.org/10.1590/1807-1929/agriambi.v21n6p398-403

De Boer, W., \& Kowalchuk, G. A. (2001). Nitrification in acid soils: Micro-organisms and mechanisms. Soil Biology and Biochemistry. https://doi.org/10.1016/S0038-0717(00)00247-9

Forest, F. E., Virginia, W., Webster, J. R., Berry, D. F., Burger, J. a, \& Kelly, C. N. (2010). Carbon and nitrogen cycling in watersheds of contrasting vegetation types in the Fernow Experimental Forest. West Virginia.

Gilliam, F. S., Yurish, B. M., \& Adams, M. B. (2001). Temporal and spatial variation of nitrogen transformations in nitrogen-saturated soils of a central Appalachian hardwood forest. Canadian Journal of Forest Research. https://doi.org/10.1139/cjfr-31-10-1768

Handayanto, E., Cadisch, G., \& Giller, K. E. (1995). Manipulation of quality and mineralization of tropical legume tree prunings by varying nitrogen supply. Plant and Soil. https://doi.org/10.1007/BF00017685

Kelly, C. N., Schoenholtz, S. H., \& Adams, M. B. (2011). Soil properties associated with net nitrification following watershed conversion from Appalachian hardwoods to Norway spruce. Plant and Soil. https://doi.org/10.1007/s11104-011-0755-5

Krave, A. S., Van Straalen, N. M., \& Van Verseveld, H. W. (2002). Potential nitrification and factors influencing nitrification in pine forest and agricultural soils in Central Java, Indonesia. Pedobiologia. https://doi.org/10.1078/0031-4056-00161

Kyveryga, P. M., Blackmer, A. M., Ellsworth, J. W., \& Isla, R. (2004). Soil pH Effects on Nitrification of Fall-Applied Anhydrous Ammonia. Soil Science Society of America Journal. https://doi.org/10.2136/sssaj2004.0545

Li, J., Shi, Y., Luo, J., Zaman, M., Houlbrooke, D., Ding, W., \& Ghani, A. (2014). Use of nitrogen process inhibitors for reducing gaseous nitrogen losses from land-applied farm effluents. Biology and Fertility of Soils. https://doi.org/10.1007/s00374-013-0842-2

Mancinelli, R. L., \& McKay, C. P. (1988). The evolution of nitrogen cycling. Origins of Life and Evolution of the Biosphere. https://doi.org/10.1007/BF01808213

Myrold, D. D., Bottomley, P. J., Schepers, J. S., \& Raun, W. R. (2008). Nitrogen Mineralization and Immobilization. https://doi.org/10.2134/agronmonogr49.c5

Nishio, T., \& Fujimoto, T. (1990). Kinetics of nitrification of various amounts of ammonium added to soils. Soil Biology and Biochemistry. https://doi.org/10.1016/0038-0717(90)90059-9

Palm, C. A., \& Sanchez, P. A. (1991). Nitrogen release from the leaves of some tropical legumes as affected by 
their lignin and polyphenolic contents. Soil Biology and Biochemistry. https://doi.org/10.1016/0038-0717(91)90166-H

Paul, E. A., \& Clark, F. E. (1988). Soil microbiology and biochemistry. Soil Microbiology and Biochemistry. https://doi.org/10.2307/4003217

Philippot, L., \& Germon, J. C. (2005). Contribution of Bacteria to Initial Input and Cycling of Nitrogen in Soils. Microorganisms in Soils: Roles in Genesis and Functions. https://doi.org/10.1007/3-540-26609-7_8

Purwanto, E.Handayanto, D. Suprayogo, \& dan K. Hairiah. (2006). Impact of forest conversion into coffee agroforestry on nitrification rates: population inventory and activities of nitrifying bacteria. Agrivita, 28(3), 267-285.

Purwanto, H. (2009). Soil Biology (Environmental Management Soil Study). Publisher Indonesia Cerdas. Yogyakarta.

Raun, W.R., \& Johnson, G.V. (1999). Improving nitrogen use efficiency for cereal production. Agronomy Journal, 91, 357-363. https://doi.org/10.2134/agronj1999.00021962009100030001x

Robinson, C., Schinner, F., Ohlinger, R., Kandeler, E., \& Margesin, R. (2006). Methods in Soil Biology. The Journal of Ecology. https://doi.org/10.2307/2960521

Ross, D. S., Lawrence, G. B., \& Fredriksen, G. (2004). Mineralization and nitrification patterns at eight northeastern USA forested research sites. Forest Ecology and Management. https://doi.org/10.1016/j.foreco.2003.08.004

Rosswall, T. (1982). Microbiological regulation of the biogeochemical nitrogen cycle. Plant and Soil. https://doi.org/10.1007/BF02182752

Roviqowati, F., Purwanto, P., \& Hartati, S. (2015). Vertisols N-Mineral Dynamics In Several Litter Quality Combination and N-Sweet Corn Uptake. Sains Tanah - Journal of Soil Science and Agroclimatology. https://doi.org/10.15608/stjssa.v11i1.206

Sahrawat, K. L. (2008). Factors affecting nitrification in soils. Communications in Soil Science and Plant Analysis. https://doi.org/10.1080/00103620802004235

Sahrawat, Kanwar L. (1996). Nitrification inhibitors, with emphasis on natural products, and the persistence of fertilizer nitrogen in the soil. Nitrogen Economy in Tropical Soils. https://doi.org/10.1007/978-94-009-1706-4_37

Ste-Marie, C., \& Paré, D. (1999). Soil, pH and N availability effects on net nitrification in the forest floors of a range of boreal forest stands. Soil Biology and Biochemistry. https://doi.org/10.1016/S0038-0717(99)00086-3

Tietema, A., Emmett, B. A., Gundersen, P., Janne Kjønaas, O., \& Koopmans, C. J. (1998). The fate of $15 \mathrm{~N}-$ labelled nitrogen deposition in coniferous forest ecosystems. Forest Ecology and Management. https://doi.org/10.1016/S0378-1127(97)00123-0

Van Groenigen, J. W., Huygens, D., Boeckx, P., Kuyper, T. W., Lubbers, I. M., Rütting, T., \& Groffman, P. M. (2015). The soil n cycle: New insights and key challenges. SOIL. https://doi.org/10.5194/soil-1-235-2015

Verhagen, J. (1997). Site specific fertiliser application for potato production and effects on N-leaching using dynamic simulation modelling. Agriculture, Ecosystems and Environment. https://doi.org/10.1016/S0167-8809(97)00086-8

Verstraete, W., \& Focht, D. D. (1977). Biochemical Ecology of Nitrification and Denitrification. https://doi.org/10.1007/978-1-4615-8219-9_4

Yao, H., Gao, Y., Nicol, G. W., Campbell, C. D., Prosser, J. I., Zhang, L., \& Singh, B. K. (2011). Links between ammonia oxidizer community structure, abundance, and nitrification potential in acidic soils. Applied and Environmental Microbiology. https://doi.org/10.1128/AEM.00136-11

\section{Copyrights}

Copyright for this article is retained by the author(s), with first publication rights granted to the journal.

This is an open-access article distributed under the terms and conditions of the Creative Commons Attribution license (http://creativecommons.org/licenses/by/3.0/). 